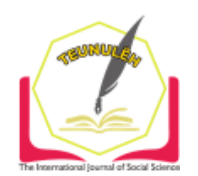

Jurnal Ilmiah Teunuleh

The International Journal of Social Sciences

Vol. 2, Issue. 2, June 2021

E-ISSN: 2746-4393

\title{
THE USE OF ANIMATION MOVIE TOWARDS STUDENTS SPEAKING ABILITY THROUGH E-LEARNING
}

\author{
Sri Wahyuni ${ }^{\mathbf{1}}$ \\ Universitas Bina Bangsa Getsmpena \\ sri@bbg.ac.id \\ Maulizan² \\ rosdiana@bbg.ac.id \\ Yulidarawati ${ }^{3}$ \\ yulidarawati@gmail.com
}

\begin{abstract}
This study is the use of English animation movie as a media in teaching speaking through e-learning process, and it is intended to improve the speaking ability of the students. The methodology used is classroom action research and SMA Keberbakatan Olahraga Negeri (SMAKON) Aceh as a research subject. The source of the data in this study is from the communication between teacher and students in teaching and learning process through e-learning. The instruments are used observation and test. The data observation is analyzed by using qualitative method and the data from the test is analyzed by using quantitative method. In the pre-test result, there are only 1 student who complete pre-test from the total 4 students who followed pre-test. The percentage is still under the predictive criteria, specifically $\geq 80 \%$ from the average score of students that is $\geq 65$. Meanwhile, the post-test shown that all four students got exhaustive score with the percentage reached $50 \%$ and the score average reached 50 . It means that $X$ IPS-1 student's improving speaking by using animation movie on e-Learning process at SMAKON is in good category. On the observation result of X IPS-1 students' improving speaking on e-Learning process improves. Before the researcher implemented animation movie, the percentage only reached $25 \%$, either student's improving on eLearning process or students' activity during teaching and learning process. Then, the percentage increased to $100 \%$ for students' improving speaking on e-Learning process and $83.75 \%$ for students' activity during teaching and learning process after animation movie has implemented.
\end{abstract}

Keywords: Speaking, Animation Movie, E-Learning 


\section{A. Introduction}

In speaking English, the students need a special learning method or technique to improve their ability, because most of Indonesian does not use English as their main language to communicate in daily life. Thus, English speaking have some components to be mastered by the learners to understand all of the components in speaking English, such as grammar, vocabulary, pronunciation, and spelling. Those skills are important to be mastered without ignoring each component. Bloomfield in Bashir (2011, p. 35) states that language is a formal system of signs governed by grammatical rules of combination to communicate meaning. This definition stresses the fact that human language can be described as closed structural systems consisting of rules that relate particular signs to particular meaning.

Therefore, speaking skill is the most important skill to acquire foreign or second language learning. Among the four key language skills, speaking is deemed to be the most important skill in learning a foreign or second language. According to the expert Brown and Yuke in the journal written by RAO $(2019$, p. 8), state that speaking is the skill that the students will be judged upon most in real life situations.

Kosar and Bedir (2014, pp. 12-26) state speaking is an interactive process of constructing meaning that consists of producing and receiving information. Sidik (2013: 682-688) argues that it shows that oral interactions can be characteristic in terms of routines, which are conventional ways of presenting information that can focus on information of interaction.

From the statement above, it can be concluded that speaking is one of the languages skills that focus on verbal interaction. This can produce, send or receive information accurately and smoothly. This can turn out, send or receive data accurately and smoothly. The speaker should concentrate on vocabulary, grammar, furthermore as pronunciation. It means that this activity involves two or more people in whom the participants are both hearers and speakers having to react to whatever they hear and make their contributions at a high-speed, so every participant has intention or a collection of intention that he needs. So, English teachers should activate the students' speaking ability by providing communicative language activities and interesting media in the classroom, and then giving them the opportunities to practice their speaking skills as much as possible.

Bailey defines in the journal written by Laksana $(2016$, p. 5) speaking is a process of interaction where speakers intend to build meaning through producing, receiving, and processing information. From those theories, it can be concluded that speaking 
skill is related to communication. Speaking is a skill to use a language appropriately to express ideas, opinions, or feelings in order to give or get information and knowledge from other people who do communication.

Speaking could be a method of interaction. Wherever speakers shall build that means by manufacturing, receiving, and process info. From those theories, it will be concluding that speaking talent is expounded to communicate. Speaking could be a talent to use a language suitably to specific plan, opinion, or feeling to offer or get info and data from others who do communication.

Meanwhile, in the teaching and learning process carried out by schools or other educational institutions, it mean that there are teachers and students who involved in the teaching and learning process, students' need to get an appropriate methods or techniques to improve their speaking ability, such as by applying movies on e-Learning process, especially animation movie. This method can be applied by providing three choices of movies that were watched for each stage by the students. Then the teacher asked the students to talk like the actors in its movie. This method will be very interesting for young learners, especially for senior high school students because they will talk about the essence of the movie they have been watching.

In this pandemic era, teaching learning in every single school is running through e-learning. E-learning itself is refers to the use of information and communication technologies to enable the access to online learning or teaching resources. In some definitions e-learning encompasses more than just the offering of wholly on-line courses. According to the expert Maltz in the journal written by Arkorful and Abaido (2014, p. 398) state that, the term of e-Learning is applied in different perspectives, including distributed learning, online-distance learning, as well as hybrid learning. ELearning as the use of information and communication technologies in diverse processes of education to support and enhance learning institutions of higher education, and include the usage of information and communication technology as a complement to traditional classrooms, online learning refers to the attainment and the use of knowledge that are predominantly facilitated and distributed by using electronic devices.

For students, e-Learning provides them with an extra selection of learning vogue additionally to ancient learning. E-Learning is not restricted by time and area because it can take place at home, at work or anyplace via computers or mobile devices connected to the internet. Meanwhile, with the internet, students are starting to offer a wider range of interactive learning experiences as well as faster communication with 
students via email. Since then, the development of e-Learning has been in line with technological developments, such as e-Learning that researchers do, such as WhatsApp, Google Meet, Zoom, etc.

Wisloski (2011, p. 80), states that this is particularly convenient for students who are learning and working at the same time. Finally, e-Learning students can completely control the space and rhythm of their studies as they are not required to attend physical classes in school. Arguelles, Callejo and Ferrero (2013, pp. 268-285), argue that few research efforts are focused on how key elements of e-Learning service quality affect e-Learning student loyalty through the intermediary role of e-Learning student satisfaction.

E-learning, additionally referred to as online learning or electronic learning is the acquisition of knowledge that takes place through electronic technologies and media. In easy language, e-Learning is outlined as learning that is enabled electronically. Typically, e-Learning is conducted on the internet, wherever students will access their learning materials online at anywhere and time. E-Learning most often takes place in form of online courses, or online programs. Clark and Mayer $(2016$, p. 7) define elearning as instructions delivered through digital devices with the intent of supporting learning. For educational school, e-learning brings perhaps the most potential uses of all. Who are properly able to adapt to the standards of internet learning will undoubtedly see increased profitability.

Algahtani (2011, p. 399), divided e-Learning into two basic types, consisting of computer-based and internet based e-Learning. The computer-based learning contains employment of a full vary of hardware and software generally that are offered for the employment of knowledge and communication Technology and additionally every part can be used in either of two ways: computer-managed instruction and computerassisted-learning. In computer assisted-learning, computers are used instead of the traditional methods by providing interactive software as a support tool within the class or as a tool for self-learning outside the class. In the computer-managed-instruction, computers are employed for the purpose of storing and retrieving information to aid in the management of education.

Almosa argue in the journal written by Arkorful and Abaidoo (2014, pp. 399-400) the internet-based learning is a further improvement of the computer-based learning, and it makes the content available on the internet, with the readiness of links to related knowledge sources, for example e-mail services and references which could be used by learners at any time and place as well as the availability or absence of teachers or 
instructor. Algahtani (2011, p. 400), describe the completely online mode as "synchronous" or "asynchronous" by the application of optional timing of interaction.

Meanwhile, this research is done for X IPS 1 students at SMA Keberbakatan Olahraga Negeri. Hopefully this research can increase the closeness of students in learning English as a foreign language by using animation movie in English as a first step to improve their ability, especially in speaking English skill. Thus, the researcher limited the used of English animation movie as a media in teaching speaking through e-learning process.

\section{B. Method}

This research method is Classroom Action Research (CAR) that will be useful to solve students' problem in learning English at classroom. Moreover, this study will use mix method by describing how this method is able to achieve the goal of this study. The researcher will do this study in SMA Keberbakatan Olahraga Negeri (SMAKON) Aceh.

This study has been done for 3 months from January 2021 until March 2021 which is included preparation until the report of this study result. This study effective implementation will be performing for 3 months, specifically from December 2020 until Febuary 2021. This study was intended to improve the speaking ability of the students using animation movie as the teaching media. This Classroom Action Researh (CAR) comprises planning, Action, observation, and reflection.

\section{Research Subject}

The subject of this study is the students of X IPS 1 at SMA Keberbakatan Olahraga Negeri (SMAKON) Aceh, but because of pandemic COVID-19 situation as well as the teaching and learning process is performed through e-Learning, so the researcher only takes 4 students from 21 students as the subject because these 4 students are the most diligent students who attend e-Learning class and want to submit the assignment.

\section{Data and Source of Data}

The data of this study is taken from the result of student's observation and test. There are two parts of worksheet, such as pre-test worksheet and post-test worksheet. The data also taken from the attendance of the subject in every e-learning class is performed. 


\section{Research Instrument and Technique of Data Collection}

The source of the data in this study is from the communication between teacher and student. It is including students' activity and attitude in teaching and learning process through Zoom Cloud meeting room. The data will be collected by some techniques, those are:

\section{Observation}

Observation is an activity that makes the researcher to observe the object which is will be researched directly. This observation activity is used to be one of the instruments to collect the data because the researcher can identify the changes which are happening in this study. This research used a direct observation, namely by observing and writing a report about students' activity and attitude during the teaching and learning process through Zoom Cloud meeting room. This activity has to be written naturally like what is happening during the teaching and learning process. The researcher observed the students' solemnness, attention, and liveliness during the teaching and learning process. The researcher also used the check list table as the instrument of this observation to see how the effectiveness of the animation movie method in E-learning process works.

2. Test

Test is used to measure the students' ability in teaching and learning process. Test will be done twice in speaking. The first test as known as pre-test to identified the students' ability in understanding simple word of animation movie before explain it to them. The second test as known as post-test to help the researcher in identifying the improvement of students' understanding and improving their speaking ability in eLearning process after explained and used the animation movie method. The researcher would identify the accuracy of filling the task and classifying it into spelling and pronunciation.

\section{Technique of Data Analysis}

Data analysis is the most important part in a study after all of the data are collected. This technique is used to find the truth of the test toward the hypothesis that has been formulated in a study. The data from the observation will be analyzed by using qualitative method and the data from the test will be analyzed by using quantitative method. 
The Use of Animation Movie Towards Students Speaking Ability Through E-Learning

Table 1. Assessment Form of improving of Speaking

\begin{tabular}{|c|c|c|c|}
\hline No. & Aspect & Score & Criteria \\
\hline \multirow{3}{*}{1.} & \multirow{3}{*}{ Pronunciation } & 50 & $\begin{array}{l}\text { Very good: pronunciation the } \\
\text { word of the movie correctly }\end{array}$ \\
\hline & & 30 & $\begin{array}{l}\text { Good: pronunciation the word } \\
\text { of the movie correctly and a } \\
\text { few words of movie not } \\
\text { correctly }\end{array}$ \\
\hline & & 25 & $\begin{array}{l}\text { Adequate: pronunciation the } \\
\text { word of a half of movie } \\
\text { correctly but the other words } \\
\text { are not classified correctly or } \\
\text { left empty }\end{array}$ \\
\hline \multirow{4}{*}{2} & \multirow{4}{*}{ Spelling } & 50 & $\begin{array}{l}\text { Very good: spells the word of } \\
\text { movie correctly }\end{array}$ \\
\hline & & 30 & $\begin{array}{l}\text { Good: spells the word of the } \\
\text { movie corectly and a few word } \\
\text { of movie not correctly. }\end{array}$ \\
\hline & & 25 & $\begin{array}{l}\text { Adequate: spells the word of a } \\
\text { half of movie correctly but the } \\
\text { other words are not classified } \\
\text { correctly or not write. }\end{array}$ \\
\hline & & 15 & $\begin{array}{l}\text { Lack: spell the word of movie } \\
\text { not correctly }\end{array}$ \\
\hline
\end{tabular}

Table 2. Students' Activity Observation Sheet

\begin{tabular}{|c|c|c|c|}
\hline No. & Aspect of Assessment & Numeral & Percentage \\
\hline 1. & $\begin{array}{l}\text { Students write the all subtitle in animation } \\
\text { movies }\end{array}$ & & \\
\hline 2. & $\begin{array}{l}\text { Students tell about the intention of } \\
\text { caracters of animation movie }\end{array}$ & & \\
\hline 3. & Students spell the word & & \\
\hline 4. & $\begin{array}{l}\text { Students try to pronuncing by correcting } \\
\text { word }\end{array}$ & & \\
\hline
\end{tabular}

Students' activity and exhaustiveness learning percentage will be measured by using percentage formula by Sudjono (in Rafiqa, 2015) below:

$$
\mathrm{P}=\frac{f}{N} \times 100 \%
$$

Annotation for students' exhaustiveness learning:

$\mathrm{P}=$ Percentage number

$f=$ Amount of students who are exhaustive 
$\mathrm{N}=$ Total number of students

Annotation for students' learning activity

$\mathrm{P}=$ Percentage number

$f=$ Amount of students' score every test

$\mathrm{N}=$ Total students' score for every tests

According to Arikunto (2006: 206), here are the categories which are determined to scan the average percentage of students' exhaustiveness learning and students' activity that was acquired.

Table 3. Assessment Category of Improving of Speaking Test

\begin{tabular}{|c|c|}
\hline Percentage & Category \\
\hline $75 \%<\mathrm{P}<100 \%$ & Very good \\
\hline $50 \%<\mathrm{P}<75 \%$ & Good \\
\hline $25 \%<\mathrm{P}<50 \%$ & Adequate \\
\hline $0 \%<\mathrm{P}<25 \%$ & Lack \\
\hline
\end{tabular}

\section{Performance Indicator}

Mulyasa (2006, pp. 101-102) said that if the observation reaches the score $\geq$ $70 \%$. Meanwhile, the predictive criteria is if there are $\geq 80 \%$ of the students got score $\geq 65$ in the final test of the action, it means that the study is included into a success criteria. If this study cannot reach the success criteria, the researcher will do the second cycle but if this study can reach the success criteria, the researcher will continue this study to the next step.

\section{Research Procedure}

Procedure and research method that is used in this study is Classroom Action Research (CAR) which consists of 2 cycles with every cycle is done consistent to the plan and changes that will be happened from what has been planned. Every cycle will be done in $2 \mathrm{x}$ meeting. This study will be done as well as the classroom action research principals; those are planning, treatment, observation, and reflection.

According to kemmis and Mc Taggar cited by David Nunan, Classroom Action Research is a group activity, and a descriptive research carried out by a teacher in his or her own classroom, without the involvement of others, which is aimed at increasing our understanding rather than changing the phenomenon under investigation, would not be considered by these commentators to be action research. 


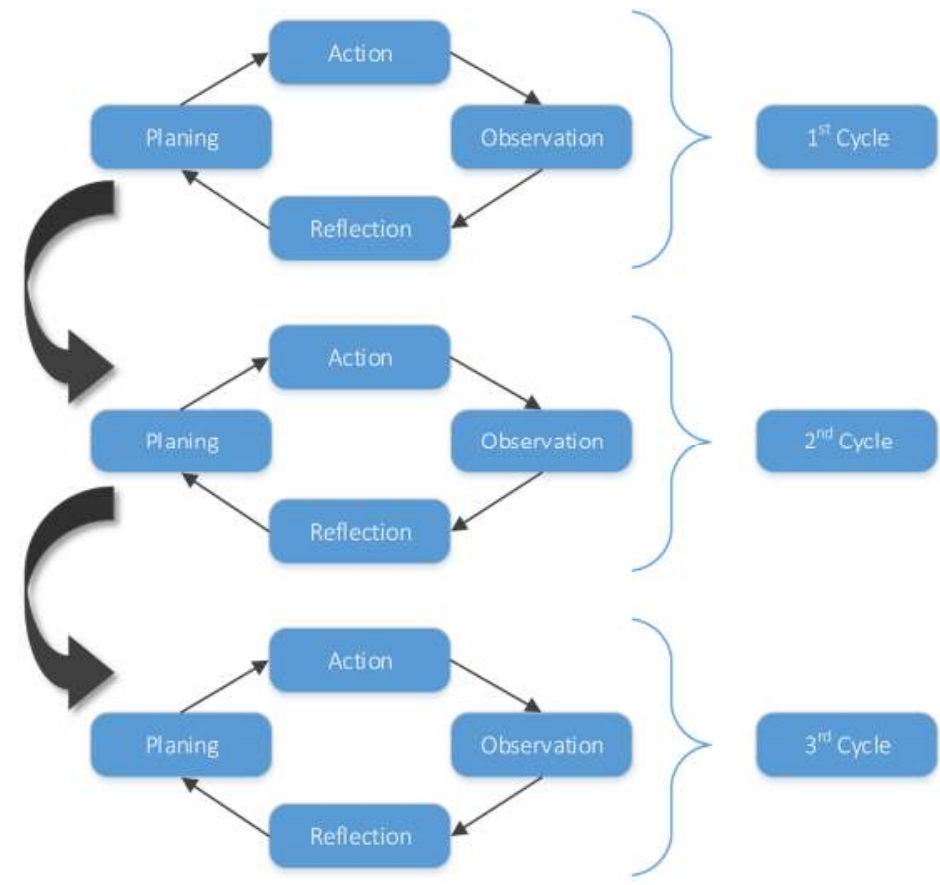

Picture 1. Classroom Action Research Design

\section{Finding and Discussion}

\section{Finding}

Before doing a research, the researcher performs a test to see how far the XIPS1 students understand English vocabulary. This test is done with the instruction: "write the word that you hear on animation movie before i give to you the move which have subtitle." This pre-test was followed by the X IPS-1 students of SMA Keberbakatan Olaharaga Negeri (SMAKON) yet it was only 4 students because of pandemic COVID-19 situation nowadays, the students who join the meeting are only a few and those 4 students are only the students who want to submit assignments from the total 21 students The result of pre-test will be explained and described in the table below.

Table 4. Pre-test Result Analysis of X IPS-1 Students in Improving Speaking by Using Animation at SMA Keberbakatan Olahraga Negeri (SMAKON)

\begin{tabular}{|c|l|c|l|}
\hline No. & \multicolumn{1}{|c|}{ Student's Name } & Score & \multicolumn{1}{|c|}{ Annotation } \\
\hline 1. & CH & 0 & Not complete \\
\hline 2. & KR & 80 & Complete \\
\hline 3. & UH & 0 & Not complete \\
\hline 4. & NS & 0 & Not complete \\
\hline \multicolumn{2}{|c|}{ Total Score } & \multicolumn{2}{c|}{20} \\
\hline \multicolumn{2}{|c|}{ Average }
\end{tabular}


Sri Wahyuni, Maulizan, Yulidarawati

\begin{tabular}{|l|c|}
\hline Total Complete Pre-test & 1 student \\
\hline Complete Pre-test Percentage & $25 \%$ \\
\hline Total Not Complete Pre-test & 3 students \\
\hline Not Complete Pre-test Percentage & $75 \%$ \\
\hline
\end{tabular}

Based on the table above can be conclude that X IPS-1 student's improving on eLearning process by using animation movie at SMA Keberbakatan Olahraga Negeri (SMAKON) is in the lack category. Because there are only 1 student who complete pretest from the total 4 students who followed pre-test. The percentage is still under the predictive criteria, specifically $\geq 80 \%$ from the average score of students that is $\geq 65$. This is happened because students did not give their attention when teacher was explaining. It is also because the students never practice their speaking of English by reading English text, so they cannot know and identify the word to pronunciation and spelling even if they are only simple English words. Here are the data of students' activity observation.

Table 5. X IPS-1 Students' Activity Observation Result at SMA Keberbakatan Olahraga Negeri (SMAKON)

\begin{tabular}{|c|l|c|c|}
\hline No. & \multicolumn{1}{|c|}{ Aspect of Assessment } & Numeral & Percentage \\
\hline 1. & $\begin{array}{l}\text { Students write the all subtitle in } \\
\text { animation movies }\end{array}$ & 2 & $50 \%$ \\
\hline 2. & $\begin{array}{l}\text { Students tell about the intention of } \\
\text { caracters of animation movie }\end{array}$ & 2 & $50 \%$ \\
\hline 3. & Students spell the word & 2 & $50 \%$ \\
\hline 4. & $\begin{array}{l}\text { Students try to pronuncing by } \\
\text { correcting word }\end{array}$ & 2 & $50 \%$ \\
\hline Average Percentage & & $50 \%$ (Good) \\
\hline
\end{tabular}

Based on the table above can be conclude that the average percentage of students' activity in classroom reaches $50 \%$ with good category. Based on the result of pre-test and students' activity observation that has been done, the teacher as the writer of this study tried to implement a learning method which can help to improve students' speaking on e-Learning process by using animation movie. The writer hopes that animation movie method can make it better, it means that this animation movie method is hoped to help improving X IPS-1 students' speaking on e-Learning process at SMA Keberbakatan Olahraga Negeri (SMAKON). 


\section{Description of Cycle 1}

The writer already did the four steps of classroom action research, specifically planning, action, observation, and reflection. The following was a brief explanation of the cycle 1 . Every activity will be explained as follows:

1. Planning

Before doing the research, the writer determined the material to be taught to the students, prepared the lesson plan, found problems that are happened in classroom, found the best method to solve the problems, prepared media, observation guideline, and students' worksheet.

2. Action

In this step, the teacher applied the ac4tion based on lesson plan. The action of this research consisted of two meetings. The first meeting was done on January $20^{\text {th }}$, 2021 at first grade of SMA Keberbakatan Olaharaga Negeri (SMAKON) Aceh. The teacher taugh the students about expressing intention by using power point persentation through Zoom Cloud meeting room because of COVID-19 situation which made students have to follow teaching and learning process from home.

The first, the teacher showed some video to brainstorm students about the material. Then, the teacher informed about what the material and the purpose of the material. The next, the teacher explained about the expressing intention, kinds of expressing intention, generic structure of expressing intention and the language features of narative text.

The last meeting in cycle 1 was done on $23^{\text {th }}$ January 2021. In this meeting, the teacher re-explained the material about the expressing intention This test was taken as the result of cycle 1 .

\section{Observation}

In the observation step, the teacher was helped by the collaborator. It was done during the teacher implemented the strategy in the classroom through Zoom Cloud meeting room. The collaborator observe by using the observation checklist and fieldnotes. There were two observation checklist; observation checklist for the teacher and observation checklist for the students.

The first, the result of the teacher observation checklist was shown good in almost all of aspects, but, there were some notes that were written by the collaborator. The first, the teacher's voice should be louder to make the students listening to the lesson clearly. Then, the teacher should pay attention to the whole students, especially for the students who did not understand about the lesson. 
The second was the result of the students' observation checklist and field-notes, almost of the students understand about the material that they learned because they were familiar with expressing intention.

The result of the post-test will be explained and described in the table below.

Table 6. Post-test Result Analysis of X IPS-1 Students in Improving Speaking at SMA Keberbakatan Olahraga Negeri (SMAKON) in Cycle 1

\begin{tabular}{|c|l|c|l|}
\hline No. & \multicolumn{1}{|c|}{ Student's Name } & Score & \multicolumn{1}{c|}{ Annotation } \\
\hline 1. & CH & 85 & Complete \\
\hline 2. & KR & 85 & Complete \\
\hline 3. & UH & 0 & Not complete \\
\hline 4. & NS & 0 & Not complete \\
\hline Total Score & \multicolumn{2}{c|}{170} \\
\hline Average & \multicolumn{2}{c|}{ 2 students } \\
\hline Total Complete Post-test & \multicolumn{2}{c|}{ 2 students } \\
\hline Complete Post-test Percentage & \multicolumn{2}{c|}{$50 \%$} \\
\hline Total Not Complete Post-test & \multicolumn{2}{|c|}{} \\
\hline Not Complete Post-test Percentage &
\end{tabular}

Based on the table above the readers can see that all four students got exhaustive score with the percentage reached $50 \%$ and the score average reached 50 . It means that X IPS-1 student's improving speaking by using animation movie on eLearning process at SMA Keberbakatan Olahraga Negeri (SMAKON) is in good category. It also means the students' improving on e-Learning process has improved since the animation movie method help them. The data of observation result of students' activity will be described in the table below.

Table 7. X IPS-1 Students' Activity Observation Result at SMA Keberbakatan Olahraga Negeri (SMAKON)

\begin{tabular}{|c|l|c|c|}
\hline No. & \multicolumn{1}{|c|}{ Aspect of Assessment } & Numeral & Percentage \\
\hline 1. & $\begin{array}{l}\text { Students write the all subtitle in } \\
\text { animation movies }\end{array}$ & 2 & $50 \%$ \\
\hline 2. & $\begin{array}{l}\text { Students tell about the } \\
\text { intention of caracters of } \\
\text { animation movie }\end{array}$ & 3 & $75 \%$ \\
\hline 3. & Students spell the word & 2 & $50 \%$ \\
\hline 4. & $\begin{array}{l}\text { Students try to pronuncing by } \\
\text { correcting word }\end{array}$ & 3 & $62,5 \%$ (Good) \\
\hline
\end{tabular}


The table above explained that students' activity percentage improved. The percentage reached good category. In this cycle, the students gave their attention when the teacher was explaining materials. Besides, the students wanted to ask question to the teacher when they did not understand the instruction. In addition, all four students wanted to answer teacher's questions and did not know to spelling the word. The following is a chart to ilustrate the students score improvement from pleminary cycle into cycle 1.

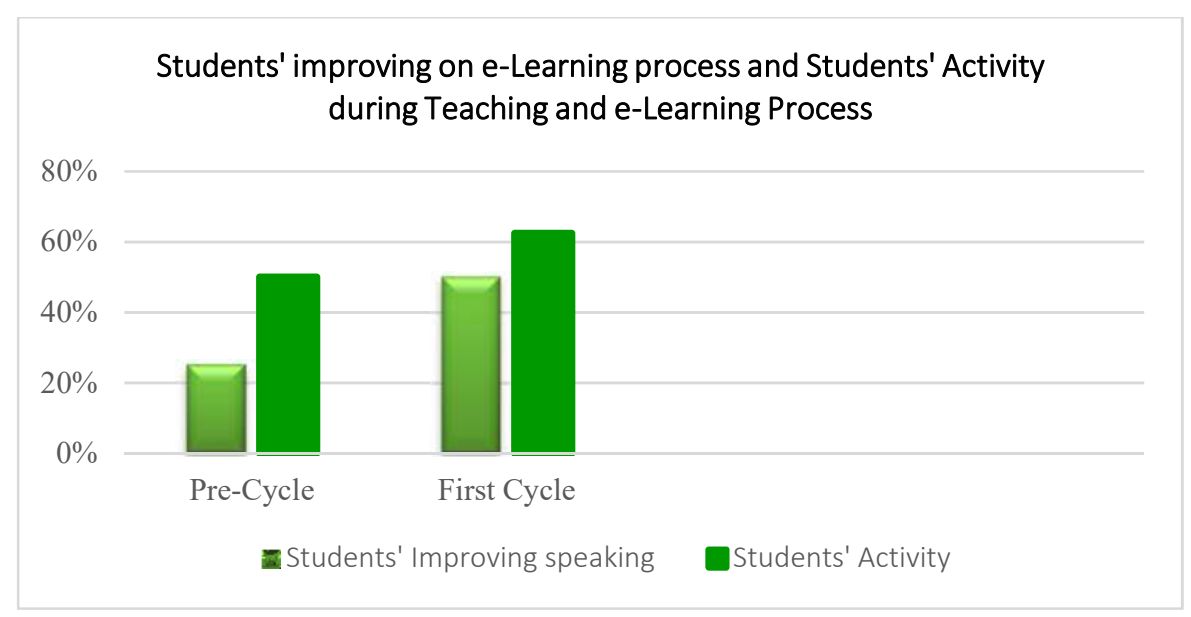

Chart 1 . The percentage of the students who improve speaking and students activity the standard score from the pleminary cycle to the cycle 1

\section{Reflection}

The result of the speaking test showed 2 students who can pass standard score. It showed that students scores were improve 12,5\%. Even though there was an improved score of students activity the standard score, the indicator of success has not been achieve yet. It means that the reserach had not been successful yet. Moreover, based on the teacher and students' checklist, the teacher was shown good in almost all of aspects. But, there were some notes that were written by the collaborator. The first, the teacher's voice should be louder, the teacher should pay attention to the whole student, and the teacher was less on guided and controlled the students.

From the reflection and discussion with the collaborator, the teacher would do some effort to improve the students' speaking ability on e-Learning by using animation movie method in the next cycle. 


\section{Description of Cycle 2}

Cycle 2 was conducted based on the result of reflection from cycle 1. Cycle 2 was held on two meetings and it used the similar steps to cycle 1, planning, action, observation, and reflection.

1. Revised Plan

The plan was similar to the cycle 1 but there were more some revises. The teacher prepared the lesson plan about expressing intention but it focused more on language features of the expressing intention. The teacher also prepared the syllabus, the materials in the power point persentation, the example of expresssing intention, and observation checklist.

The learning materials and the lesson plan of this research were designed based on the syllabus and the curriculum of the school and the steps of animation movie method. This research had been planned to be held on January $24^{\text {th }} 2021$.

\section{Action}

This step conducted by applying Animation Movie Method based on the revised plan. This step was consisted of two meetings. The first meeting was held on $25^{\text {th }}$ January 2021. At this meeting, the teacher started the lesson by asking the students' understanding about the expressing intention. Then the teacher explained about the language features of expressing intention lesson. After that, the teacher explained about animation movie in brief and what the students had to do.

The second meeting was conducted on $2^{\text {rd }}$ Febuary 2021. This step was similar to the cycle 1 . The first, the teacher gave the students one video without subtitle. Then the teacher ask the students to identify about expressing intention based on caractersof animation movie. After that write down the word that they listen from the video. The last, the teacher would like to give the same video with subtitle, after that ask to students to compare they result before watching animation video with subtitle. Then, try pronuncing and spelling the word based on the video. This test was taken as the result of cycle 2 .

\section{Observation}

In the observation step, the teacher still helped by the collaborator to fill the observation checklist. There were two observation checklist; observation checklist for the teacher and observation checklist for the students.

The first was a teacher observation checklist . the teacher was done well in all aspects. The teacher's voice was louder. The teacher delivered the material briefly and 
clearly. The teacher explained the material about the language features of expressing intention. Then the teacher gave the students a clear example of expressing intention. The teacher can control and monitored students better than the cycle 1. Although, the teacher did not control the whole of the students but the condition of the class was more effective than the cycle 1.

The second was the student's observation checklist. The result showed that the students' anttention and participants were better than cycle 1 . The students paid attention to the teacher explanation. They also asked actively to the materials that they did not understand. They also had a better understanding about how to use animation movie method in speaking expressing intention. In the second cycle, the students showed more enthusiasm in speaking expressing intention.

In addition, there was speaking ability test in observe stages. The speaking ability test was held at the end of the cycle 2 . The students' score in cycle 2 can be seen on the table below.

Table 8. Pre-test Result Analysis of X IPS-1 Students in Improving Speaking by Using Animation Movie at SMA Keberbakatan Olahraga Negeri

\begin{tabular}{|c|l|c|c|}
\hline No. & \multicolumn{1}{|c|}{ Student's Name } & Score & \multicolumn{1}{c|}{ Annotation } \\
\hline 1. & CH & 80 & Complete \\
\hline 2. & KR & 90 & Complete \\
\hline 3. & UH & 80 & Complete \\
\hline 4. & NS & 85 & Complete \\
\hline Total Score & \multicolumn{2}{c|}{335} \\
\hline Average & \multicolumn{2}{c|}{ 4 students } \\
\hline \multicolumn{2}{|c|}{ Total Complete Pre-test } & \multicolumn{2}{c|}{0 students } \\
\hline Complete Pre-test Percentage & \multicolumn{2}{c|}{$0 \%$} \\
\hline \multicolumn{2}{|c|}{ Total Not Complete Pre-test }
\end{tabular}

Based on the table above the readers can see that all four students got exhaustive score with the percentage reached $100 \%$ and the score average reached 83,75 . It means that X IPS-1 student's improving speaking by using animation movie on e-Learning process at SMA Keberbakatan Olahraga Negeri (SMAKON) is in very good category. It also means the students' improving on e-Learning process has improved since the animation movie method help them. The data of observation result of students' activity will be described in the table below. 
Table 9. X IPS-1 Students' Activity Observation Result at SMA Keberbakatan Olahraga Negeri (SMAKON)

\begin{tabular}{|c|l|c|c|}
\hline No. & \multicolumn{1}{|c|}{ Aspect of Assessment } & Numeral & Percentage \\
\hline 1. & $\begin{array}{l}\text { Students write the all subtitle in } \\
\text { animation movies }\end{array}$ & 3 & $75 \%$ \\
\hline 2. & $\begin{array}{l}\text { Students tell about the } \\
\text { intention of caracters of } \\
\text { animation movie }\end{array}$ & 3 & $75 \%$ \\
\hline 3. & Students spell the word & 4 & $100 \%$ \\
\hline 4. & $\begin{array}{l}\text { Students try to pronuncing by } \\
\text { correcting word }\end{array}$ & 3 & $81,25 \%$ (Very good) \\
\hline
\end{tabular}

Based on the table above, the resercher concluded that there is improvement from cycle 1 to cycle 2 . The chart below ilustrates the students improvement from the cycle 1 into cycle 2 .

Students' improving on e-Learning process and Students' Activity during Teaching and e-Learning Process

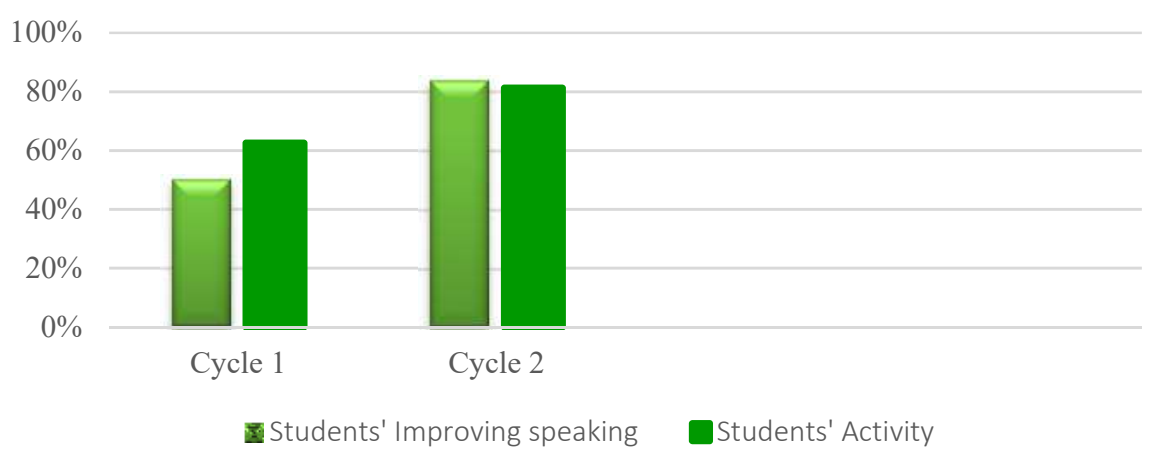

Chart 2. The percentage of the students who improve speaking and students activity the standard score from the cycle1 to the cycle 2

\section{Reflection}

The result of the cycle 2 showed an improvement from the previous cycle. It was shown that there were percentage between cycle 1 into cycle 2 . The teacher had succesfully improved the students' ability in speaking expressing intention by using animation movie method that was shown by the students who passed the standard score. It was achieve the indicator of success. In addition, the students participantion and attention from the start to the end of the lesson was better than the first cycle. 


\section{Discussion}

Classroom Action Research was performed by the researcher in a two cycle with four steps, such as planning, action, observation, and reflection. This study is based on the problems which are happened in classroom which included X IPS-1 students' is improving speaking on e-Learning process and XIPS-1 students' activity during teaching and learning process at SMA Keberbakatan Olahraga Negeri (SMAKON). The students still cannot pronunce and spell word well. So, the writer implements animation movie on e-Learning process to improve students' speaking ability. If the results improve, it means that the students' improving on e-Learning process by using animation movie improves too.

Animation movie method is the method which makes the students have to read and write the word on animation movie and classify word that intention by the caracter of that movie. This method is believed can make the students are interested in doing the assignment because it is animation movie, funny and consists of challenge that makes students feel challenged to speak the word.

X IPS-1 students' improving on e-Learning process by using animation movie method is able to improve, either individual or classical. In pre-cycle, the percentage of students' improving in e-Learning process is $25 \%$ with lack category increase to $50 \%$ with good category in $1^{\text {st }}$ cycle of the study and increase to $83.75 \%$ with very good category in $2^{\text {nd }}$ cycle.. However, the students' activity percentage during teaching and learning process also increased from $25 \%$ with lack category in pre-cycle to $50 \%$ with good category in $1^{\text {st }}$ cycle into $83.75 \%$ with very good category of this study. The development which was happened between pre-cycle, $1^{\text {st }}$ cycle, and $2^{\text {nd }}$ cycle can be seen in the chart below:

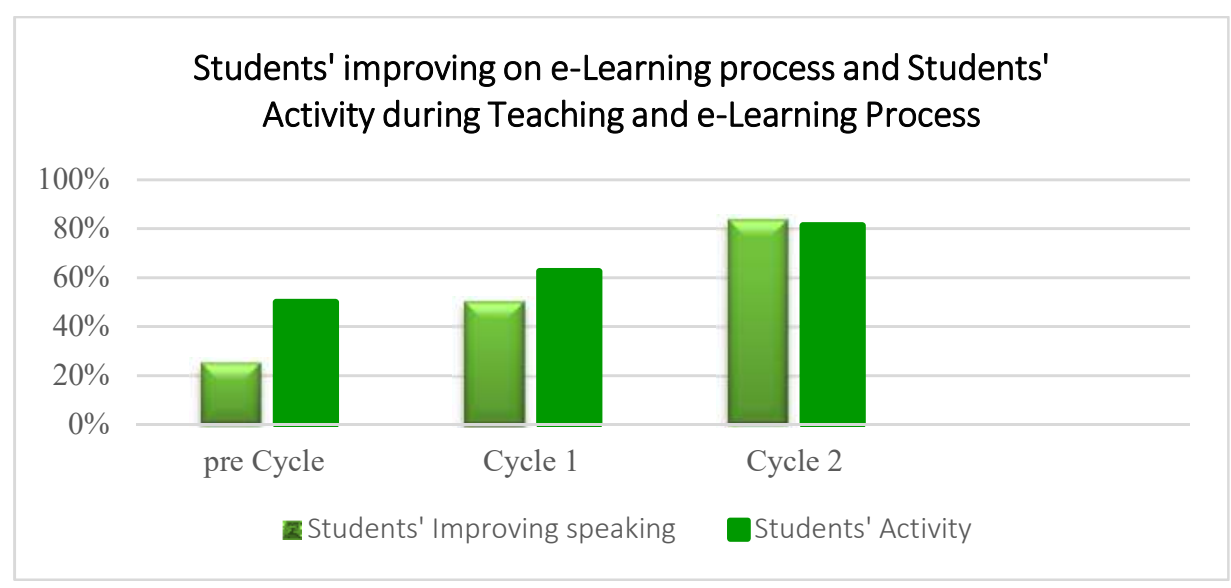

Chart 3. The percentage of the students who improve speaking and students activity the standard score from the pre cycle, cycle1 to the cycle 2 
Based on the picture above, XIPS-1 students' improving speaking on e-Learning process improves. Before the researcher implementanimation movie method, the percentage only reached $25 \%$, either student's improving on e-Learning process or students' activity during teaching and learning process. Meanwhile, the percentage increased to $100 \%$ for students' improving speaking on e-Learning process and $83.75 \%$ for students' activity during teaching and learning process after animation movie has implemented.

By observation in the pleminary study, the researcher found that main problem of speaking were lack of variety of techniques uses by the teacher during the teaching and learning process and students motivation. By learning from those problem, the researcher implemented the animation movie in cycle and prepare all material needed well. As result thw students were interested in joining every step of this technique and could be active.

Finally, using animation movie could improve not only the students' speaking ability but also their participants in the class. It can be seen from the observation, pre test and post test. So in the last cycle, the researcher satisfied with the result, because students speaking ability were increase after taugh by using animation movie.

\section{Conclusion}

Based on the analysis of the results, either student understands in learning English vocabulary or students' activity during teaching and learning process, it can be concluded that, the implementation of animation movie method on e-Learning process to X IPS-1 students at SMA Keberbakatan Olahraga Negeri (SMAKON) was successful. It can be seen from the percentage of the students' improving speaking on e-Learning process and students' activity, either in pre-cycle or $1^{\text {st }}$ cycle. It increased from $50 \%$ to $100 \%$ as students' improving speaking on e-Learning process and from $62.5 \%$ to $81.75 \%$ as students' activity during teaching and learning process.

\section{Bibliography}

Igahtani, M. 2015. The Importance of Vocabulary in Language Learning and How to be Taught. International Journal of Teaching and Education: International institute of Social and Economic Sciences.

Algahtani. dkk. 2011. Evaluating the Effectiveness of the E-learning Experience. Universities in Saudia from Male Student's perceptions: Durham University. 
Vol. 2, Issue. 2, June 2021

The Use of Animation Movie Towards Students Speaking Ability Through E-Learning

Arkorful,V. dan Abaidoo, N. 2014. The Role of E-learning, The Advantages of its Adoption in Higher Education. International Journal of Education and Research.

Arguelles, M. dkk. 2013. Dimensions of Perceived Service Quality in Higher Educational Virtual Learning Environments. Universitas and Knowledge Society Journal.

Arikunto, S. 2006. Penelitian Tindakan Kelas, Jakarta: PT. Bumi Aksara.16

Bashir, M., (2011). factor effecting students' English speaking skills. Universitas of Education Bank Road Campus Lahore, 2(1), 35.

Brown, H.D. 2004. Language Assessment Principles and Classroom Practic. Testing, Assessing, and Teaching. San Francisco: Longman.

Kosar, G. and B. Hasan. 2014. Strategies-based instruction A means of improving adult EFL learners' speaking skills. International Journal of Academy.

Laksana, A. J. 2016. The Effectiveness of Using Chain Story Game in Teaching Speaking at the Eight Grade Students of SMP Negeri. Skripsi. Purwokerto: Education Faculty Muhammadiyah University Purwokerto.

Mulyasa, E. 2006. Kurikulum Berbasis Kompetensi, (Bandung: Remaja Rosdakarya). 101102

Nguyen, T. 2015. The Effectiveness of Online Learning: Beyond no Significant Different and Future Horizons. MERLOT Journal of Online Learning and Teaching.

Rao, P. S. 2019. The Importance of Speaking Skills in English Classroom. Alford Council of International English and Literature Journal (ACIELJ).

Susanto, A. and Fazlinda, A. 2016. English Vocabulary Acquisition through Vocabulary Learning Strategy and Socio-Educational Factors A Review. Applied Science and Technology.

Sidik, A. S. 2013. Improving Students Speaking Ability Through Practice Rehearsa. Languange Edu: Malang.

Wisloski, J. 2011. Online Education Study: As Enrollment Rises, Institutions see Online Education as a 'critical part' of growth. Journal of Higher Education Theory and Practice.

Wahyuni, A. D. 2016. The Effectiveness of Short Movie for Teaching Speaking. Skripsi. Kalimanah: Education Faculty Muhammadiyah University Purwokerto. 